\title{
Influence of phosphorus on copper sensitivity of fluvial periphyton: the role of chemical, physiological and community-related factors
}

\author{
Alexandra Serra $\cdot$ H. Guasch $\cdot$ W. Admiraal • \\ H. G. Van der Geest • S. A. M. Van Beusekom
}

Accepted: 8 December 2009/Published online: 19 December 2009

(C) The Author(s) 2009. This article is published with open access at Springerlink.com

\begin{abstract}
The influence of eutrophication of fluvial ecosystems (caused by increased phosphorus concentrations) on periphyton $\mathrm{Cu}$ sensitivity is explored from a multi-scale perspective, going from the field to the laboratory. The study design included three tiers: a field study including the characterization of land use and the ecological state of the corresponding river sections in the Fluvià River watershed, an experimental investigation performed with natural periphyton from the previously studied stream sites in indoor channels, and finally a culture study in the laboratory. Results showed that differences in copper sensitivity of natural periphyton communities followed the gradient of nutrient concentration found in the field. Results from the culture experiments demonstrated that both, P-conditions during growth and P-content in the media are important factors modulating the toxicological response of algae to $\mathrm{Cu}$. The observations from this study indicate that the ecological effects of metal pollution in rivers might be obscured by eutrophication.
\end{abstract}

Keywords Eutrophication - Cu toxicity $\cdot$ Periphyton · Phosphate $\cdot$ Rivers

\author{
A. Serra $(\bowtie) \cdot H$. Guasch \\ Faculty of Sciences, Institute of Aquatic Ecology, University \\ of Girona (UdG), Campus Montilivi, 17071 Girona, Spain \\ e-mail: alexandra.serra@udg.edu
}

W. Admiraal - H. G. Van der Geest - S. A. M. Van Beusekom Department of Aquatic Ecology and Ecotoxicology, University of Amsterdam, Kruislaan 320, 1098 SM Amsterdam,

The Netherlands

\section{Introduction}

Among the many ecosystem stressors, eutrophication and metal pollution are the two major environmental problems in many developed and developing countries (Wang and Dei 2006). Agricultural activity is one of the major sources of phosphorus and nitrogen to aquatic ecosystems (Carpenter et al. 1998; Eckholm et al. 2000). At watershed scale, excessive inputs of phosphorus derived from agricultural practices are closely linked to eutrophication of surface waters (Johnson et al. 1997). In addition to fertilizers, human activities have also contributed to a progressive increase in other substances, especially heavy metals in aquatic environments (Nriagu 1979; Ma et al. 2003; Andrade et al. 2004) resulting in potentially toxic levels for aquatic organisms. As metal pollution is often associated with eutrophic conditions in aquatic ecosystems (LópezFlores et al. 2003), it is considered of great interest to elucidate the interaction between nutrients and metal toxicity, and this investigation specifically focuses on the interaction between copper and phosphorus which are commonly found together in fluvial systems draining industrial and urban watersheds (Twiss and Nalewajko 1992). Metal bioavailability, and thus the toxic effects on the biota, can be modulated by the inorganic and organic chemistry of the water body (Genter 1996). Water pH, conductivity, temperature, nutrient availability and inorganic and organic ligands have been described as factors strongly influencing metal toxicity (Stumm and Morgan 1981; Luoma 1983; Meador 1991; Campbell 1995; Sunda and Huntsman 1998; Meylan et al. 2004).

Several investigations have focused on the interrelationships between trace metals and nutrients in phytoplankton and algal biofilms (Wang and Dei 2001; Interlandi 2002; Ivorra et al. 2002; Riedel and Sanders 2003; Guasch 
et al. 2004). Many studies support the hypothesis that metal toxicity is reduced in response to increases in $\mathrm{P}$ concentrations (Harding and Whitton 1977; Say and Whitton 1977; Chen 1994). On the other hand, several studies indicate that metals can induce nutrient limitation which can result in reduced algal growth (e.g. Nalewajko and Olaveson 1994; Paulsson et al. 2002). In these cases nutrient enrichment has been shown to compensate this effect of the metal as, for example, P-addition may allow the formation of cellular polyphosphate bodies which can bind intracellularly heavy metals in a detoxified form (Jensen et al. 1982; Peterson et al. 1984; Twiss and Nalewajko 1992). For instance, a direct influence of phosphorus (P) supply on copper toxicity to algae has also been demonstrated (Hall et al. 1989; Twiss and Nalewajko 1992; Hashemi et al. 1994; Nalewajko and Olaveson 1994; Guasch et al. 2004). Although much information about the interaction between nutrients and heavy metal toxicity is already available, especially in phytoplankton or single species studies, field testing and studies at community level remain scarce (e.g. Guasch et al. 2004).

Periphytic communities are ubiquitous and ecologically important components of many rivers and streams, as they are in the basis of the fluvial food web they have been used for assessing the quality of these ecosystems (Boston et al. 1991) including metal pollution (Johnson et al. 1978; Ramelow et al. 1992; Ivorra et al. 1999). Based on the opportunity to evaluate the response of numerous species simultaneously, community ecotoxicology can provide a much broader context for the assessment of environmental contamination than the study of individual species (Clements and Newman 2002).

In the present investigation, we hypothesize that eutrophication will lead to a reduction of copper sensitivity in natural periphyton communities due to variations in metal bioavailability as well as the phosphate regime during growth. Although both phosphorus and nitrogen supplies contribute to freshwater eutrophication (OECD (Organization for Economic Cooperation, Development) 1982), we have focused on the relationship between phosphorus (P) and copper $(\mathrm{Cu})$ toxicity because phosphorus can often be the main limiting nutrient in freshwater environments (Horne and Goldman 1994). This is also the case of our study area. In addition, $\mathrm{P}-\mathrm{Cu}$ interaction was also of interest due to the contribution of phosphorus in metal detoxification mechanisms (e.g. Twiss and Nalewajko 1992; Paulsson et al. 2002).

In order to test our hypothesis, the study design included three tiers: a field study including the characterization of land use and the ecological state of the corresponding river sections in the Fluvià River watershed, an experimental investigation performed with natural periphyton from the previously studied stream sites in indoor channels, and finally a toxicological study using algal cultures in the laboratory. Our multi-scale experimental design aimed to elucidate the relative role of the different processes contributing to the interaction effects of $\mathrm{P}$ and $\mathrm{Cu}$ on fluvial periphyton communities. Specifically the contribution of phosphorus conditions during growth and phosphorus/ copper ratio in media on $\mathrm{Cu}$ toxicity was evaluated in algal cultures as well as in natural periphyton communities. Whereas the use of algal cultures allows control of biological and environmental conditions, tests using natural communities incorporate the ecological variability of the natural system (Cairns and Niederlehner 1987; Navarro et al. 2002; Sabater et al. 2007).

\section{Materials and methods}

Study design

This study was structured in three general sections: a field study, a microcosm study using experimental channels and natural periphyton communities and finally, a laboratory experiment with algal cultures. The field study was conducted in order to characterize the Fluvià watershed and was also used to choose the most suitable sites for the community ecotoxicology study. Natural periphyton communities collected from the chosen river sites were thereafter used to investigate the contribution of trophic conditions during growth on $\mathrm{Cu}$ toxicity. Finally, a benthic diatom was cultured under different $\mathrm{P}$ concentrations and it was also exposed to $\mathrm{Cu}$ in the short term in order to elucidate the effect of cell nutrient status on $\mathrm{Cu}$ toxicity. Moreover, the influence of P-supply in the media on $\mathrm{Cu}$ toxicity was also evaluated on both, periphyton and algal cultures (Fig. 1).

\section{Field study}

The Fluvià River, located in northeast Spain, is a calcareous Mediterranean river which drains a volcanic zone, declared a Natural Park in 1982. The sampling included six sites located in the headwater of the River Fluvià and its main tributaries corresponding to first- and second-order streams (Fig. 2).

The physicochemical parameters of each site were taken on five sampling dates from October 2002 to November 2003. On each sampling, water $\mathrm{pH}$, temperature, conductivity, and dissolved oxygen were measured in the field. One litre of water samples per site were collected for their analysis in the laboratory. Samples were immediately filtered by GF/C Whatman glass microfibre filters, and refrigerated $\left(4^{\circ} \mathrm{C}\right)$. They were analysed between $24 \mathrm{~h}$ for ammonium and alkalinity measurements and frozen for 


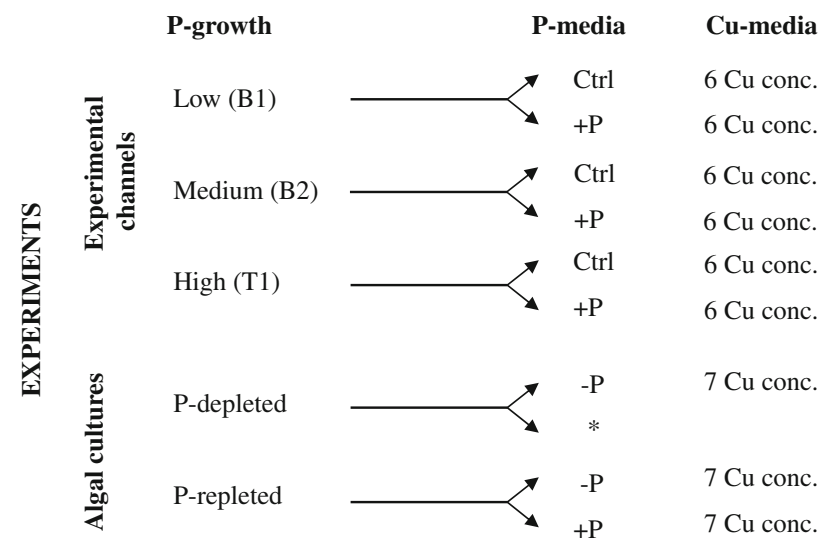

Fig. 1 Scheme of the experimental design used in the algal cultures and in the experimental channels. P-growth refers to phosphorus conditions during growth of periphyton and the algal cultures. P-media refers to the phosphorus conditions during the toxicity tests. $\mathrm{Cu}$-media refers to the copper concentrations ( $\mathrm{Cu}$ conc.) during the toxicity tests. Experiments with algal cultures were done in duplicate (EXP 1 and EXP 2 in the text). * The treatment P-depleted/ $+\mathrm{P}$ was not included in the experimental design in order to avoid interactions of a starved culture with the supply of phosphorus in the media during the experiment

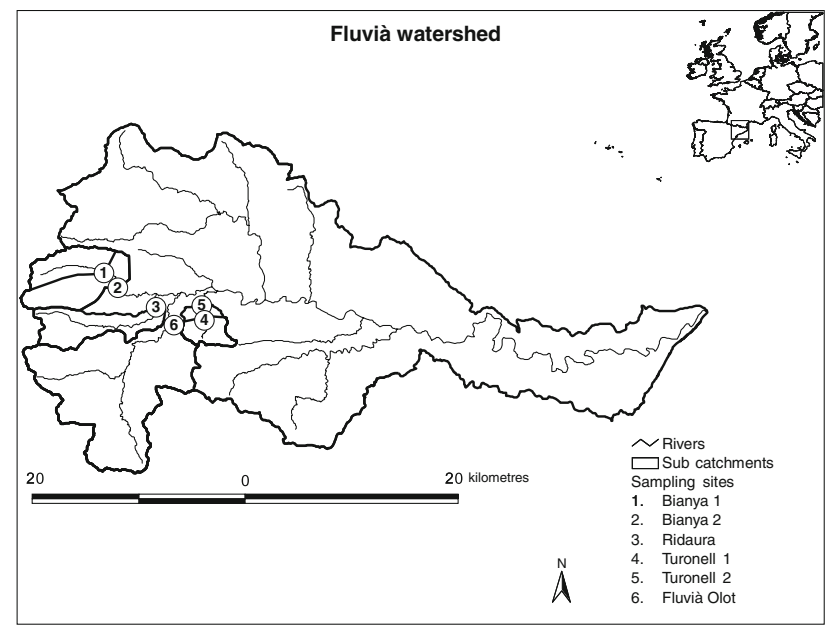

Fig. 2 Map of the Fluvià watershed and location of the study sites. The sub-catchments are separated by a solid line

Soluble Reactive Phosphorus (SRP), nitrate and nitrite analyses following American Public Health Association (APHA) (1989).

Periphyton samples for algal biomass measurements, were obtained from $1 \mathrm{~cm}^{2}$ of biofilm scraped off three stones from each sampling point in triplicate. Chlorophyll- $a$ concentration was obtained after extraction in $90 \%$ acetone, and sonication for $5 \mathrm{~min}$ and determined spectrophotometrically, following Jeffrey and Humphrey (1975).

Land uses and land covers of each sub-catchment draining the six sampling sites were determined by using Geographic Information System (GIS). The entire watershed was subdivided into six sub-catchments corresponding to the six sites sampled. Land use and land cover maps were based on a 1:5000 orthophotomap provided by the Institut Cartogràfic de Catalunya (ICC), and digitized contours of sub-catchments from a 1:5000 topographic map using Arc-View GIS 3.2 software (California USA) in order to obtain the percentages of the different land uses.

Experimental channels

Once the gradient of eutrophication in the field was identified, three stream sites were selected for the toxicological study (B1, B2 and T1). Natural periphyton communities from these sites were used to assess $\mathrm{Cu}$ toxicity in indoor experimental channels. P-concentration in the media was experimentally manipulated in the $\mathrm{Cu}$ toxicity tests in order to evaluate the influence of both P-limitation and $\mathrm{P}-\mathrm{Cu}$ chemical interaction on periphyton $\mathrm{Cu}$ toxicity. In these sites, metal pollution, which could interfere with results from toxicity tests, was not expected. In fact, results from a previous study carried out in the same watershed showed that the three sites selected for the present study (B1, B2 and $\mathrm{T} 1$ ) have dissolved $\mathrm{Cu}$ concentrations below $2 \mu \mathrm{g} / \mathrm{l}$ and the most polluted sites also had higher metal concentration (Guasch et al. 2009).

\section{Periphyton colonization and sampling}

Mature periphyton communities were obtained after allowing the colonization of artificial sand-blasted glass substrata $\left(1.4 \mathrm{~cm}^{2}\right)$ during 2 months (spring 2003) in each stream site. Colonized substrata were collected in the field and transported to the laboratory in cool boxes, filled with stream water (Guasch et al. 2003). Periphyton from three glass substrata from each sampling site were scraped and fixed with $4 \%$ of formaldehyde for taxonomical identification of the major algal groups under the light microscope. Three extra glass substrata from each sampling site were used for measuring algal biomass, estimated as the chlorophyll- $a$ concentration (chl- $a$ ) as described above.

The physicochemical parameters of the stream water were measured in the field in each sampling site and date and 11 of stream water was collected and transported to the laboratory for nutrient analysis as described above.

\section{$\mathrm{Cu}$ toxicity in periphyton}

For each sampling site, the colonized substrata were incubated in twelve Perspex (methyl methacrylate resin) channels using five replicates per channel (five artificial substrata). Ten litres of stream water (collected in the site of origin of each community) were recirculated in each 
channel from containers by centrifuge pumps. All the containers were placed in a water bath to maintain the field temperature. The $\mathrm{pH}$ was maintained within the range measured in the field by regular addition of diluted sulphuric acid during the incubation. The incubation was conducted inside a greenhouse allowing the penetration of natural light.

Periphyton communities from each site were exposed to two treatments, six channels were exposed to a gradient of $\mathrm{Cu}$ concentrations (referred to as controls in the text) and six channels to the same gradient of $\mathrm{Cu}$ and with a supply of $20 \mu \mathrm{M}$ phosphorus (referred to as $+\mathrm{P}$ in the text). Copper was added as copper chloride (copper titrisol, Merck, Darmstadt, Germany) to achieve nominal concentrations of $0,0.31,1,3.16,10,31.6 \mu \mathrm{M}$. Phosphorus was added as $\mathrm{KH}_{2} \mathrm{PO}_{4}$ (Fig. 1).

Analyses of $\mathrm{Cu}$ concentration of the incubation water were performed periodically using ICP-MS (Agilent 7500c, Japan).

\section{PAM fluorometry measurements}

The effects of copper and phosphorus on periphyton were measured after $18 \mathrm{~h}$ of exposure using a mini-pulse modulation chlorophyll fluorometer (PAM) (Walz Mess, und Regeltechnik, Effeltrich, Germany) as described in Guasch et al. (2002). Before the PAM measurements, periphyton was previously dark adapted for $15 \mathrm{~min}$. The effect of $\mathrm{Cu}$ on periphyton was evaluated directly on the colonized glass substrata by measuring the chlorophyll fluorescence yield of dark-adapted cells, also called chlorophyll fluorescence (Fo). This parameter was used as an indirect indicator of biomass (Serôdio et al. 1997; Rysgaard et al. 2001).

\section{Algal cultures}

Two independent sets of experiments were performed in order to obtain two replicates of the same experimental design (referred to as EXP 1 and EXP 2 in the text). Each set of experiments started after 15 days of culture growth and included six short-term toxicity tests of $\mathrm{Cu}$ toxicity on the diatom Nitzschia perminuta.

Before starting the toxicity tests, measurements of Alkaline Phosphatase Activity (APA) were performed in order to assess the degree of $\mathrm{P}$ limitation of the cultured diatom at P-repleted and depleted conditions. The procedure followed for the APA measurements is detailed below.

In each set of experiments, short-term toxicity tests were performed in duplicate using algal cultures differing in $\mathrm{P}$ regime during growth (P-depleted and $\mathrm{P}$-repleted) and/or $\mathrm{P}$ in the media during the toxicity test $(-\mathrm{P}$ and $+\mathrm{P})$ (Fig. 1).

\section{Culture preparation}

Non-axenic precultures of the diatom Nitzschia perminuta were kept in 1,000 ml Erlenmeyer flasks with 300-400 ml sterile WC medium (Guillard and Lorenzen 1972) modified as follows: the concentration of $1.0 \mathrm{mg} / 1 \mathrm{H}_{3} \mathrm{BO}_{3}$ was lowered to $0.006 \mathrm{mg} / \mathrm{l}$, and molybdenum was added as sodium salt (the same molybdenum concentration as in the original WC medium). HEPES (2-[4-(2-Hydroxyethyl)-1piperazinyl]-ethanesulphonic acid buffer was used to stabilise $\mathrm{pH}$ at 7.0. The medium was prepared following Van der Grinten et al. (2004). From the original pre-culture $1 \mathrm{ml}$ was transferred to $250 \mathrm{ml}$ Erlenmeyer flasks containing $5 \mathrm{ml}$ of glass beads $(\varnothing 490-700 \mu \mathrm{m})$ that were used as substrate for the algal development, filled with $100 \mathrm{ml}$ of new sterile WC medium as described above and containing phosphate at different concentrations. The high phosphate regime used $(100 \%)$ was that of the original WC medium, $50 \mu \mathrm{M}$ representing a saturating concentration, corresponding to the P-repleted conditions and the low phosphate regime was $5 \mu \mathrm{M}$ (10\% of the original medium), corresponding to the P-depleted conditions.

The cultures were placed in an incubator, illuminated from above with fluorescent cool-white tubes at $100 \mu \mathrm{mol} / \mathrm{m}^{2}$ s PAR (phostosynthetically active radiation) and the temperature was kept at $20^{\circ} \mathrm{C}$ using a cooling bath. The flasks were closed with cellulose plugs to allow $\mathrm{CO}_{2}$ exchange with the air. Microalgae were grown in these conditions for 15 days and growth was monitored by using PAM fluorometry measurements daily, using the chlorophyll fluorescence (Fo) as an indicator of algal biomass. Periodically and simultaneously to the PAM measurements, the number of algal cells was counted using a Burker-turk chamber, and these measurements were correlated with measurements of chlorophyll fluorescence (Fo) obtaining a good correlation $\left(r^{2}=0.83 ; \quad p<0.001\right.$; $n=80$ ) between these two variables.

\section{Cu toxicity to Nitzschia perminuta}

For each short-term toxicity test, $10-15 \mathrm{ml}$ of algae were centrifuged at $13,000 \mathrm{rpm}$ for $10 \mathrm{~min}$ and the pellet was resuspended in sterile media without EDTA, in order to avoid chelation with $\mathrm{Cu}$, to provide cell densities of approximately $1 \times 10^{5}$ cells $/ \mathrm{ml}$. Thereafter, $3 \mathrm{ml}$ of this algal suspension were exposed during $3 \mathrm{~h}$ to a growing gradient of $\mathrm{Cu}$ concentrations $(0,0.03,0.1,0.3,1,10$, $30 \mu \mathrm{M} \mathrm{Cu}$, nominal concentrations) added as copper chloride. 


\section{PAM fluorometry measurements}

PAM fluorometry was used for monitoring algal growth, using the Fo as the end point, as well as for measuring the toxic effects of $\mathrm{Cu}$ on the photosynthetic activity of the algal cells by measuring the photochemical yield $(Y)$ (Drábková et al. 2007). All the PAM measurements in the algal cultures were performed in vials of $3 \mathrm{ml}$ of algal suspension. The cells were dark adapted for $15 \mathrm{~min}$ before measurements. The parameters measured were: the chlorophyll fluorescence yield of dark-adapted cells (Fo) and the maximal signal of dark-adapted cells obtained with a saturating radiation pulse $(\mathrm{Fm})$. These parameters allow the calculation of the maximal yield of PSII as (Fm - Fo)/Fm, also called photochemical yield $(Y)$ which correspond to the capacity of dark-adapted cells to convert photon energy into chemical energy. $\mathrm{Y}$ is independent from the algal biomass. This nomenclature is according to Van Kooten and Snel (1990).

\section{Alkaline phosphatase activity measurements}

Alkaline phosphatase activity (APA) was determined spectrofluorometrically using 4-MUF-P (methylumbelliferyl phosphate) substrate from Sigma-Aldrich, following the methodology described in Romaní and Sabater (1999). From the P-repleted and P-depleted cultures of N. perminuta, $4 \mathrm{ml}$ of algal suspension were incubated with MUF-P at final concentration of $0.3 \mathrm{mM}$ (saturation conditions). Incubations were performed in the dark with continuous gentle shaking for $1 \mathrm{~h}$ at ambient stream temperature. Two blanks of sterilized medium were also incubated. After addition of $0.05 \mathrm{M}$ glycine buffer $\mathrm{pH} 10.4$ $(1 / 1 \mathrm{v} / \mathrm{v}$ ratio buffer/sample), fluorescence was measured at $455 \mathrm{~nm}$ under $365 \mathrm{~nm}$ excitation (Kontron, SFM25).

\section{Data treatment}

The ordination of sampling points and sampling dates based on the water chemistry variables was carried out with Principal Components Analysis (PCA). The variables Ammonium, Phosphate and Nitrite were previously logtransformed to obtain the normality. Differences in phosphate concentration between sampling sites and sampling dates were evaluated by means of two-way ANOVA.

In the cultures experiments, $\mathrm{Cu}$ toxicity was estimated as Effective Concentration $50 \%\left(\mathrm{EC}_{50}\right)$ by fitting the photochemical yield $(Y)$ to the four-parameter logistic curve model as described below.

$Y=\frac{(\max -\min )}{1+(x / E C 50)^{- \text {hillslope }}}$

where the variable $x$ corresponds to the $\mathrm{Cu}$ concentration of the dose-response test and the $y$ is the value of the measured end-point (i.e. yield or Fo). The parameter min equals the baseline, and max is the plateau of the curve. The parameter EC5O gives the transition center corresponding to the concentration causing $50 \%$ of inhibition of the measured end-point. The hillslope is the slope of the curve at the transition center.

In the channels experiments, $\mathrm{Cu}$ toxicity was estimated as Effective Concentration $50 \%\left(\mathrm{EC}_{50}\right)$ by fitting the chlorophyll fluorescence (Fo) to the four-parameter logistic curve model as described above.

\section{Results}

Field study

The Fluvià watershed is mainly covered by forested land ( $68 \%$ of the total surface), it is also influenced by agricultural activities ( $25 \%$ of the total surface) with some areas covered by shrub lands $(4 \%)$, urban $(2 \%)$, wetland vegetation $(<1 \%)$ and denuded space $(<1 \%)$. Land uses for each sub-catchment showed the following gradient: Bianya 1 has the highest percentage of forest and denuded space, Bianya2, Turonell 1, Ridaura, Turonell 2 and Fluvià Olot have greater surface occupied by agricultural and urban space, and shrub lands (Fig. 3).

The PCA analysis of water chemistry shows the ordination of sampling points with respect to two principal axes (Table 1, Fig. 4). The first axis explained the $41 \%$ variance and separates two sites (Turonell 2 and Ridaura) with high phosphate concentration (higher than $20 \mu \mathrm{M}$ ), high conductivity, ammonium and nitrite concentrations, from the less polluted ones (Bianya 1, Bianya 2 and Turonell 1), where phosphate concentration does not exceed $2 \mu \mathrm{M}$. The second axis explained the $22 \%$ variance, placing the Fluvià Olot site on the positive side, with high $\mathrm{pH}$, nitrate and dissolved oxygen concentrations. Algal biomass (estimated as chlorophyll- $a$ concentration) of the periphyton colonizing the stream bed was lower in sites with low nutrient

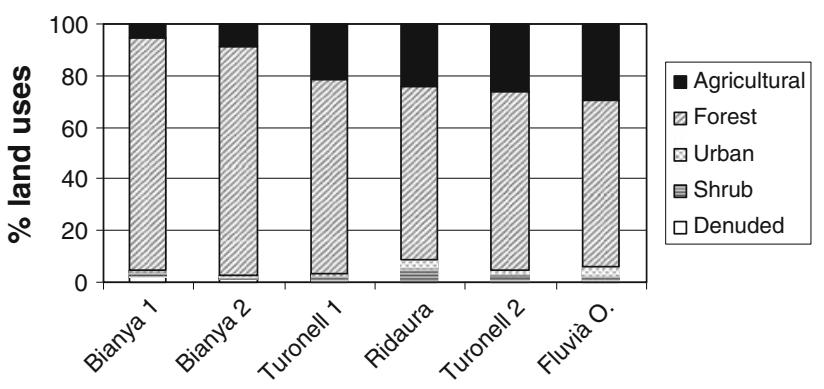

Fig. 3 Distribution of percentage of land uses in the Fluvià watershed. Agricultural, forest, built-up, shrub and denuded correspond to agricultural space, forested space, built-up space, shrub lands and denuded space, respectively 
Table 1 Physical, chemical and biological parameters measured at the studied sites in five dates from October 2002 to November 2003, and percentage of the land uses and land covers of each sub-catchment

\begin{tabular}{|c|c|c|c|c|c|c|}
\hline Parameter & Bianya 1 & Bianya 2 & Turonell 1 & Turonell 2 & Ridaura & Fluvià O. \\
\hline $\mathrm{pH}$ & $8.07 / 8.16^{*}(0.165)$ & $7.99 / 7.96 *(0.144)$ & $8.18 / 8.14 *(0.079)$ & $8.19(0.210)$ & $8.09(0.165)$ & $8.35(0.072)$ \\
\hline Temp $\left({ }^{\circ} \mathrm{C}\right)$ & $9.15(3.61)$ & $10.7(2.51)$ & $10.0(3.46)$ & $11.3(3.09)$ & $14.0(2.65)$ & $10.8(3.97)$ \\
\hline Cond $(\mu \mathrm{S} / \mathrm{cm})$ & $535 / 520 *(98.4)$ & $630 / 588 *(118)$ & $603 / 590 *(103)$ & $1914(708)$ & $1590(307)$ & $639(106)$ \\
\hline Alk (meq/l) & $6.6 / 4.56 *(1.26)$ & $7.48 / 5.04 *(1.49)$ & $7.81 / 5.64 *(1.25)$ & $7.84(1.66)$ & $7.59(1.46)$ & $6.50(1.59)$ \\
\hline Oxy (\% sat) & $93.5(4.88)$ & $93.0(4.93)$ & $95.3(8.86)$ & $93.3(7.13)$ & $80.2(12.8)$ & $113(22.4)$ \\
\hline $\mathrm{NO}_{3}(\mu \mathrm{M})$ & $31.9 / 34.3 *(18.6)$ & $115 / 109 *(68.4)$ & $155 / 172 *(89.9)$ & $174(74.2)$ & $113(75.1)$ & $261(151)$ \\
\hline $\mathrm{NO}_{2}(\mu \mathrm{M})$ & $0.016 / 0.06 *(0.019)$ & $0.305 / 0.32 *(0.107)$ & $0.128 / 0.22 *(0.068)$ & $16.3(8.98)$ & $8.38(8.46)$ & $1.36(0.490)$ \\
\hline $\mathrm{NH}_{4}(\mu \mathrm{M})$ & $1.71 / 0.46^{*}(1.90)$ & $2.03 / 1.76^{*}(2.87)$ & $1.01 / 1.18 *(0.688)$ & $67.7(77.3)$ & $72.28(88.3)$ & $3.27(2.61)$ \\
\hline $\mathrm{PO}_{4}(\mu \mathrm{M})$ & $0.085 / 0.095 *(0.059)$ & $0.155 / 0.195 *(0.053)$ & $1.05 / 1.228 *(0.349)$ & $87.4(52.8)$ & $23.2(10.4)$ & $1.02(0.529)$ \\
\hline $\mathrm{N} / \mathrm{P}$ & $424(171)$ & $1089(511)$ & $224(115)$ & $9.30(15.5)$ & $11.4(6.45)$ & $636(764)$ \\
\hline Chl- $a\left(\mu \mathrm{g} / \mathrm{cm}^{2}\right)$ & $7.06 / 20.41 *(4.65)$ & $22.6 / 26.53 *(5.11)$ & $21.9 / 33.74 *(5.48)$ & $6.70(2.89)$ & $26.2(9.95)$ & $10.2(1.49)$ \\
\hline
\end{tabular}

The values are the average and the standard error (in parenthesis) for each site of water temperature (temp), conductivity (cond), alkalinity (alk), dissolved oxygen (oxy), chlorophyll- $a$ content (chl- $a$ )

* Corresponds to the physicochemical parameters of stream water and algal biomass used in the channel experiments (June 2003)

Fig. 4 Principal Components Analysis based on the physicochemical parameters of stream water measured in each sampling date summarized in Table 1. Factor loadings correlated with a significance $p<0.05$ for each factor are indicated under an arrow for clarity. Significance of each axis is $p<0.05$

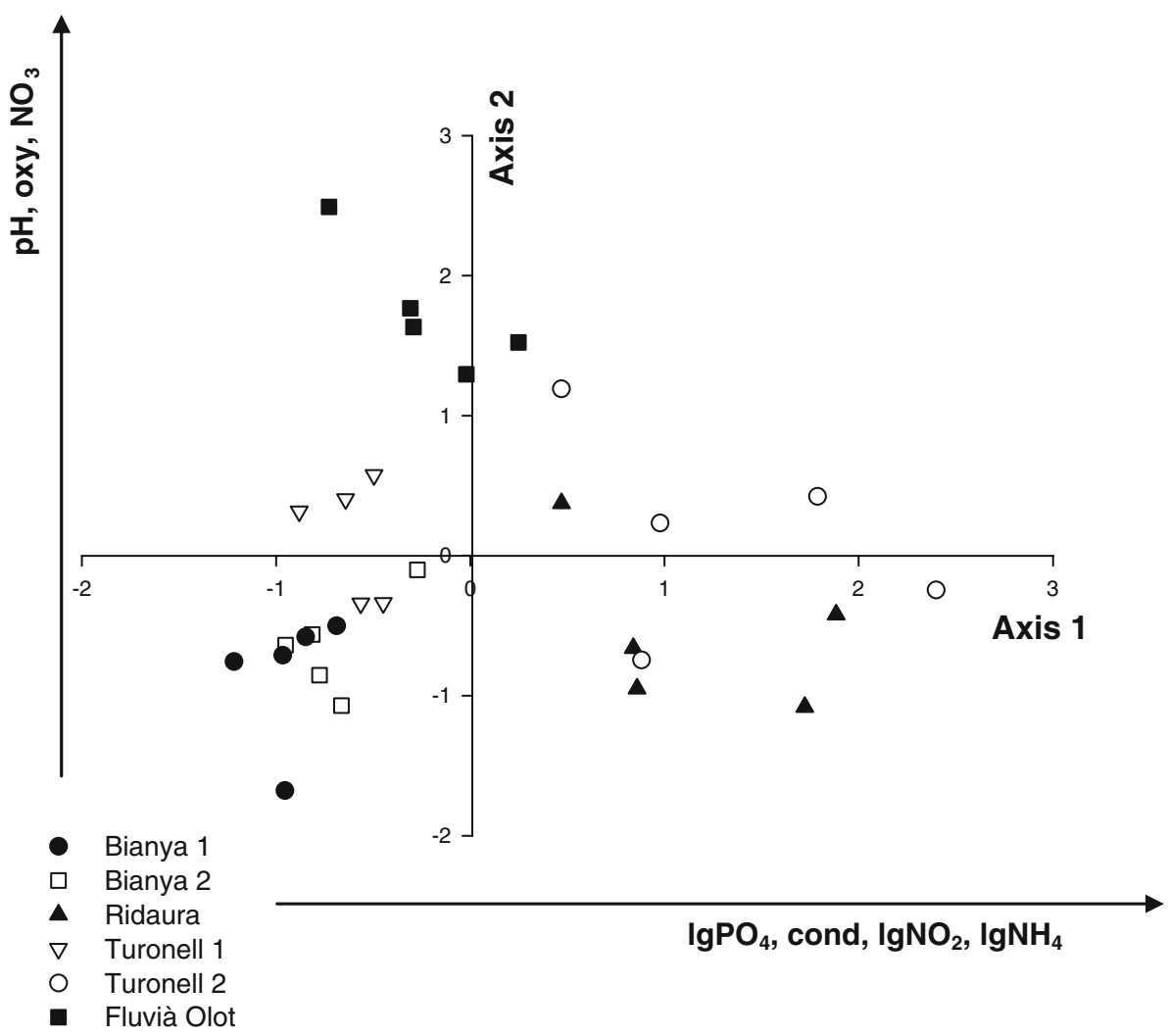

concentration and higher in those with intermediate and high nutrient concentration (Table 1).

The sites Bianya 1 (B1), Bianya 2 (B2) and Turonell 1 (T1) were selected for the toxicity study in the channels. These sites have been chosen because they have similar physical and chemical characteristics but they differ in their background nutrient concentrations (following a gradient in eutrophy derived from farming and agricultural activities developed in their sub-catchments) and this was persistent over the study period (Table 1). The selected sites showed significant differences in their phosphate background concentrations $\left(F_{2,8}=25.74 ; p<0.001\right)$ but no significant differences were found between the 5 sampling dates $\left(F_{4,8}=1.24 ; p=0.368\right)$. In addition, the three 
selected sites are the least polluted sites among the six sampled and their sub-catchments contain the highest percentage of forested surface ( $>75 \%$ of the total watershed surface).

\section{Experimental channels}

The physicochemical parameters of the stream water, and algal biomass of the periphyton used in the channel experiments, are summarized in Table 1.

Periphyton communities were dominated by green algae in B1 and B2 (76 and 78\% respectively), and were also abundant (56\%) in T1. B2 and T1 communities had a high percentage of diatoms (19 and 44\% respectively) compared to B1 $(1.8 \%)$. Cyanobacteria were more abundant in B1 (22\%) than in B2 $(2.5 \%)$ and no cyanobacteria were found in T1. In addition, B1 presented filaments of Rivularia spp., a colony-forming cyanobacterium which is characteristic of phosphorus-limited ecosystems (Guasch and Sabater 1995).

The three studied communities showed differences in their sensitivity to $\mathrm{Cu}$. In the control treatments (without $\mathrm{P}$-supply), differences in $\mathrm{Cu}$ tolerance followed the gradient of nutrient concentrations found in the field (Fig. 5, Table 2). B1 was the most sensitive community, followed by $\mathrm{B} 2$ which (1.7 times more tolerant than $\mathrm{B} 1$ ) and $\mathrm{T} 1$ (3.6 times more tolerant than B1). Comparing the ranges of the $\mathrm{EC}_{50}$ found between treatments (with and without P-supply), it was observed that $\mathrm{Cu}$ sensitivity was lower with P-supply in B1 and B2 communities while no differences in the $\mathrm{Cu}$ sensitivity were observed in the $\mathrm{T} 1$ community (Table 2). The increase of $\mathrm{EC}_{50}$ values caused by the P-supply was 3.4 and 3.6 fold in B1and B2 communities, respectively.

\section{Algal cultures}

Phosphate concentration of the culture media was $4.75 \pm 0.13 \mu \mathrm{M}$ SRP and $46.33 \pm 1.54 \mu \mathrm{M}$ in P-depleted and P-repleted treatments SRP respectively. Clear differences in Alkaline Phosphatase Activity (APA) were found between P-depleted and P-repleted cultures in both sets of experiments (EXP 1 and EXP 2) as a result of differences in $\mathrm{P}$ availability in the media during growth.

APA activities measured in P-repleted cultures were $1.67 \times 10^{-7} \pm 5.90 \times 10^{-9}$ and $7.92 \times 10^{-7} \pm 1.21 \times$ $10^{-9} \mu \mathrm{M}$ MUF/cell $\mathrm{h}$ (in EXP 1 and EXP 2, respectively). APA in the P-depleted cultures were $4.13 \times 10^{-6} \pm$ $4.70 \times 10^{-8}$ and $2.70 \times 10^{-6} \pm 5.04 \times 10^{-8} \mu \mathrm{M} \mathrm{MUF} /$ cell $\mathrm{h}$ (in EXP1 and EXP2, respectively); corresponding to 25 and 3.4 times higher than in P-repleted cultures.

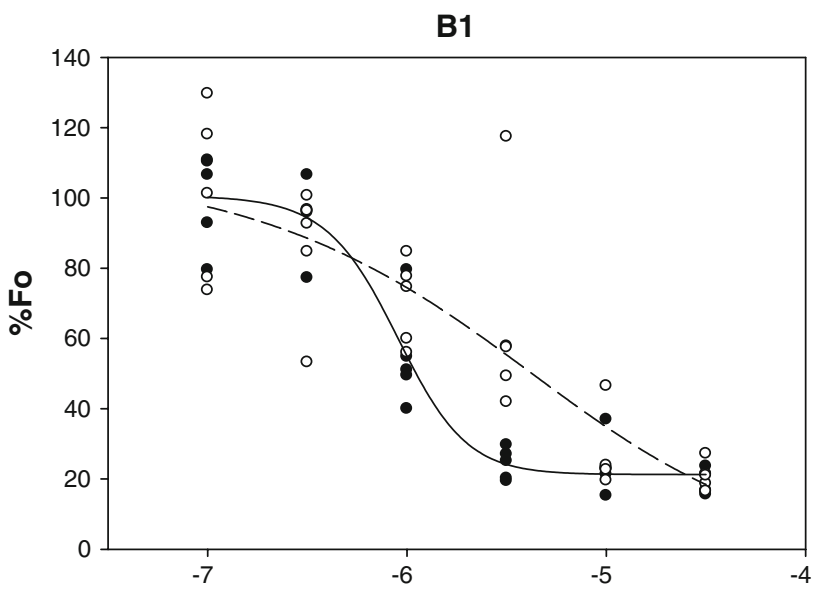

B2
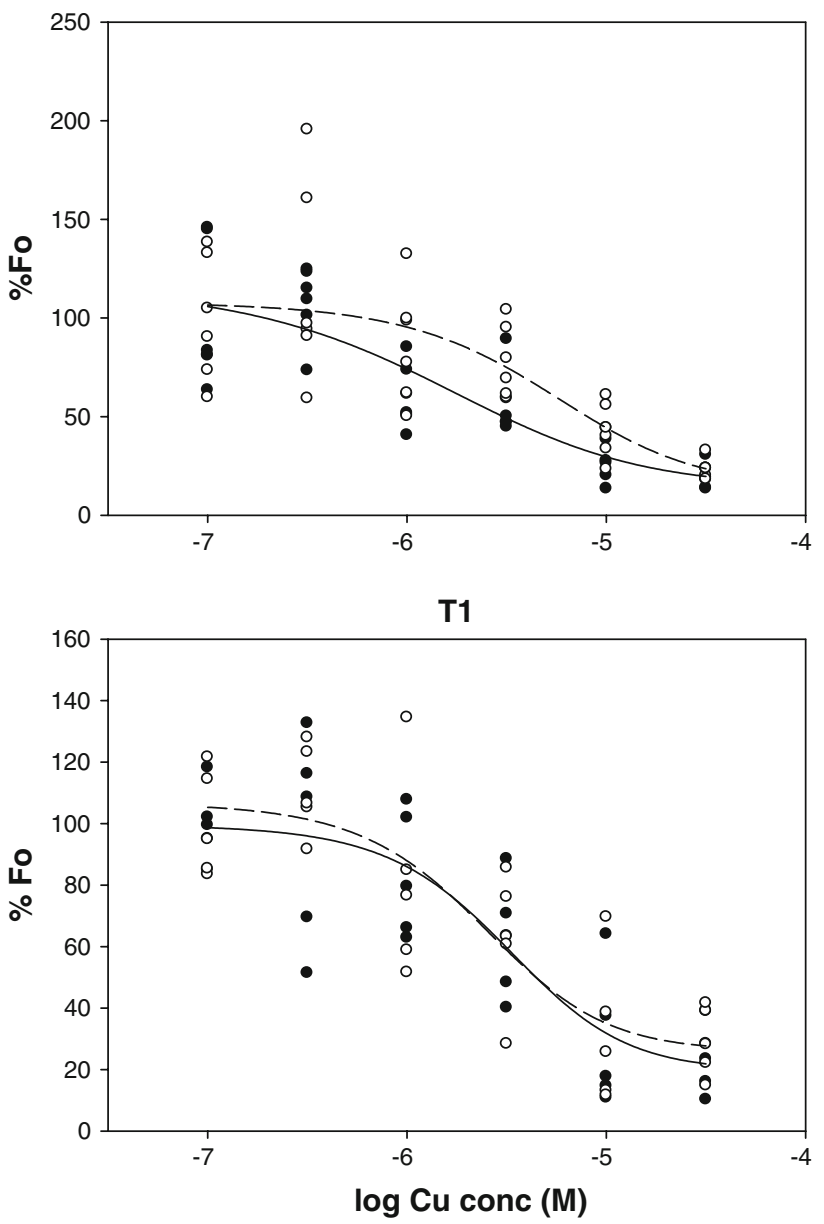

Fig. 5 Dose-response curves of the three periphyton communities (B1, B2 and T1). Plots represent the inhibition of the algal biomass (expressed as the percentage of the control of the Fo parameter) measured without (black circle) and with (white circle) P-addition. Continuous lines represents the fitting of the four-parameter logistic curves for the control treatment (without $\mathrm{P}$-addition) and dashed lines for the $+\mathrm{P}$ treatment

$\mathrm{EC}_{50}$ values for $\mathrm{Cu}$ inhibited photosynthesis were highly similar comparing both sets of experiments (Fig. 6). The results showed differences in the toxicological responses of 
Table 2 Summary of the fitting parameters $( \pm$ SE) for the three studied communities in the controls $($ Ctrl. $)$ and after $\mathrm{P}$-addition $(+\mathrm{P})$

\begin{tabular}{|c|c|c|c|c|c|c|}
\hline Parameter & B1 Ctrl. & $\mathrm{B} 1+\mathrm{P}$ & B2 Ctrl. & $\mathrm{B} 2+\mathrm{P}$ & T1 Ctrl. & $\mathrm{T} 1+\mathrm{P}$ \\
\hline Min & $\begin{array}{l}21.3 \\
\quad(18.4,24.2)\end{array}$ & $\begin{array}{l}1.97 \\
\quad(-42.7,46.7)\end{array}$ & $\begin{array}{l}14.8 \\
(-1.79,31.3)\end{array}$ & $\begin{array}{l}14.9 \\
(-14.1,43.9)\end{array}$ & $\begin{array}{l}19.9 \\
\quad(7.68,32.0)\end{array}$ & $\begin{array}{l}26.2 \\
\quad(14.8,37.6)\end{array}$ \\
\hline Max & $\begin{array}{l}100.7 \\
\quad(95.8,105.6)\end{array}$ & $\begin{array}{l}110.5 \\
\quad(73.6,147)\end{array}$ & $\begin{array}{l}117 \\
(90.2,144)\end{array}$ & $\begin{array}{l}108 \\
(94.8,122)\end{array}$ & $\begin{array}{l}99.7 \\
\quad(90.4,109.0)\end{array}$ & $\begin{array}{l}106.8 \\
\quad(95.8,117.9)\end{array}$ \\
\hline $\mathrm{EC}_{50}$ & $\begin{array}{l}0.88 \\
\quad(0.79,1.00)\end{array}$ & $\begin{array}{l}3.01 \\
\quad(1.12,8.10)\end{array}$ & $\begin{array}{l}1.47 \\
\quad(0.75,2.88)\end{array}$ & $\begin{array}{l}5.27 \\
\quad(2.61,10.7)\end{array}$ & $\begin{array}{l}3.15 \\
\quad(2.11,4.72)\end{array}$ & $\begin{array}{l}2.41 \\
\quad(1.57,3.68)\end{array}$ \\
\hline Hillslope & $\begin{array}{l}-34.3 \\
\quad(-46.5,-22.0)\end{array}$ & $\begin{array}{l}-8.41 \\
\quad(-17.1,0.27)\end{array}$ & $\begin{array}{l}-11.5 \\
\quad(-19.1,-3.84)\end{array}$ & $\begin{array}{l}-14.3 \\
\quad(-25.7,-3.01)\end{array}$ & $\begin{array}{l}-18.2 \\
\quad(-28.7,-7.60)\end{array}$ & $\begin{array}{l}-18.0 \\
\quad(-28.5,7.40)\end{array}$ \\
\hline
\end{tabular}

The effective $\mathrm{Cu}$ concentration $\left(\mathrm{EC}_{50}\right)$ is expressed in $\mu \mathrm{M}$

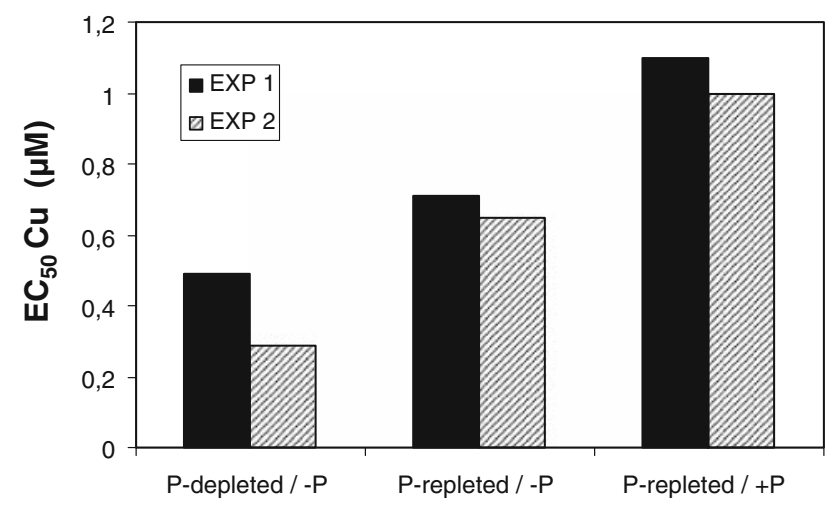

Fig. $6 \mathrm{EC}_{50}$ values calculated as the reduction of the photochemical yield $(Y)$ in percentage of the control obtained after $3 \mathrm{~h}$ of copper exposure in three different treatments. Bars represent the average of the $\mathrm{EC}_{50}$ values obtained in duplicate in the two experiments. Black and dashed bars correspond to the results obtained in the experiment 1 and experiment 2 respectively

the algae depending on both the P status of the algae and the presence of $\mathrm{P}$ in the media. Comparing results from toxicity tests performed without $\mathrm{P}$ in the media, $\mathrm{P}$-depleted cultures were 1.5-2 times more sensitive than P-repleted cultures. In conjunction, the toxicity tests performed with and without $\mathrm{P}$ in the media showed that $\mathrm{Cu}$ toxicity was reduced 1.6 times by adding $\mathrm{P}$ to the media.

\section{Discussion}

The use of short-term physiological tests with natural water as the incubation medium and intact communities as key organisms (i.e. periphyton), has the great advantage of being simple methodologically and at the same time ecologically realistic. On the other hand, these tests introduce a high degree of complexity as the chemical behaviour of toxicants is affected by local water chemistry (Guasch et al. 2003). Some of these complexities were systematically analysed using cultures.
In this investigation we explored the influence of eutrophication, and more specifically $\mathrm{P}$ enrichment, on $\mathrm{Cu}$ toxicity to periphyton from a multi-scale perspective which allowed us to integrate different degrees of complexity. Observations from natural communities exposed to different nutrient conditions in the experimental channels supported our hypothesis that eutrophication may lead to a reduction of copper sensitivity in natural periphyton. In addition, observations from algal cultures allowed us to clarify the relative contribution of phosphorus during algal growth and phosphorus in the media to copper toxicity.

Results from culture experiments, which allowed us to isolate the effect of phosphorus on Cu toxicity, confirmed that both the presence of phosphorus in the media and during algal growth leads to an increase in $\mathrm{Cu}$ tolerance of algae. Differences in $\mathrm{Cu}$ sensitivity between P-repleted and P-depleted cultures, both measured without phosphorus in the media showed that the nutritional state of the algal cells can itself explain differences in the $\mathrm{Cu}$ sensitivity of the algae. In agreement with our observations, Hall et al. (1989) also found greater copper toxicity in P-limited cultures of Chlorella vulgaris. They concluded that P-limited cells were more sensitive to $\mathrm{Cu}$, due to impaired metal exclusion/ elimination mechanisms produced by P-limitation. Rijstenbil et al. (1998) also supported this idea. Verma et al. (1993) evidenced that $\mathrm{Cu}$ toxicity in cyanobacteria was due to $\mathrm{Cu}$-induced phosphate starvation and that the exogenous addition of phosphate could antagonize the $\mathrm{Cu}$-effect in Nostoc calcicola. It has been reported that $\mathrm{Cu}$ induces the deficiency of $\mathrm{P}$ directly by the inhibition of phosphate uptake, indirectly by reducing the permeability of cell membranes (Nalewajko and Olaveson 1994). Other recent studies also supported this hypothesis; Wang and Dei (2006) found that P-deficient green algae responded much more dramatically to the increasing metal concentration than P-enriched cells. Metal toxicity in the P-deficient cells was observed within a very narrow range of ambient metal concentrations or cellular concentrations. One explanation 
was that the cells were more stressed under P-limited conditions, resulting in the greater toxicity of metals under such conditions.

In our culture experiments, when comparing results from the toxicity tests performed with and without $\mathrm{P}$ in the media, a reduction in Cu toxicity of 1.6 times was observed when $\mathrm{P}$ was added to the media (in both, EXP 1 and 2). Since the experiments were done with P-repleted cultures, it was not expected that the algae would suffer P-limitation during exposure, thus, the results support the alternative hypothesis that $\mathrm{P}-\mathrm{Cu}$ interaction in the media leads to a reduction in $\mathrm{Cu}$ bioavailability. It has been shown that phosphate precipitates with other metals and that this leads to decreased metal availability (Schulze and Brand 1978; Nalewajko and Paul 1985). However, this argument is difficult to apply to natural systems since a copper phosphate precipitate is thermodynamically unlikely to occur in natural waters, because of the presence of competing ligands.

Concerning the experiments performed with natural periphyton, since they were performed with site water, it was expected that differences in $\mathrm{Cu}$ sensitivity would integrate the effect of differences in nutritional conditions during growth as well as differences in $\mathrm{P}$ content in the water. In fact, the increase in $\mathrm{Cu}$ tolerance of periphyton grown under more eutrophic conditions (T1) compared to periphyton from more oligotrophic conditions (B1) (with a 3.6-fold increase of $\mathrm{EC}_{50}$ values) was equivalent to the change in $\mathrm{Cu}$ toxicity found in the P-limited cultures exposed to $\mathrm{Cu}$ without $\mathrm{P}$ in the media and the P-repleted cultures exposed to $\mathrm{Cu}$ with $\mathrm{P}$ in the media (around 2-3 times). Since the increase of $\mathrm{Cu}$ tolerance observed in $N$. perminuta cultures may only be attributed to the influence of $\mathrm{P}$, it indicates that differences in $\mathrm{Cu}$ tolerance observed in field communities from different sites might be related with in situ differences in $\mathrm{P}$ availability.

Higher metal tolerance found in both, algal cultures and communities, grown under more eutrophic conditions may be attributed to polyphosphate bodies (PPB) production in algal cells under non-limiting conditions. It has been well described that when the concentration of $\mathrm{P}$ in the medium is high, the levels of cellular $\mathrm{P}$ are elevated with $\mathrm{P}$ in excess of immediate cell requirements being stored as PPB (Rhee 1972, 1973). Several studies have reported the role of PPB in metal detoxification (e.g. Jensen et al. 1982; Twiss and Nalewajko 1992). These authors stated that intracellular polyphosphate is important in sequestering metals in a detoxified form and protecting the cell from the toxic effects of the metals. Thus, detoxification by PPB could also explain the high tolerance found in natural communities developed under more eutrophic conditions and P-repleted cultures in the present study, but this aspect was not directly addressed.
In the channel experiments, the exogenous addition of $\mathrm{P}$ during the toxicity tests enhanced $\mathrm{Cu}$ tolerance of the communities from the more oligotrophic sites (B1 and B2). These observations might be related to lowered nutrient limitation by the $\mathrm{P}$-addition during the tests compensating the effects of $\mathrm{Cu}$. These results are in agreement with a previous study (Guasch et al. 2004) where copper toxicity was slightly reduced when nutrients were simultaneously added in nutrient-limited communities. They suggested that the addition of metals produces a strong nutrient limitation, and that the addition of the toxicant together with phosphorus may partially compensate the inhibitory effect on the physiological response of the community. Barranguet et al. (2002) found similar results.

Chemical factors other than phosphorus are known to modify the response of natural periphyton in fluvial ecosystems. The $\mathrm{pH}$ of the media has been considered an important factor influencing the toxicity of $\mathrm{Cu}$ on periphyton (Guasch et al. 2002) and on algal cultures (Stadorub et al. 1987). These authors showed an increase in $\mathrm{Cu}$ toxicity when $\mathrm{pH}$ was reduced. This can be explained by copper speciation, because the amount of $\mathrm{Cu}^{2+}$ (which is considered the most available form of $\mathrm{Cu}$ for algae) increases at lower $\mathrm{pH}$ (Guasch et al. 2002). In our study, water $\mathrm{pH}$ in the experimental channels, which was done using natural periphyton and site water, ranged between 7.96 and 8.16 units of $\mathrm{pH}$. These $\mathrm{pH}$ differences could influence the toxicity of $\mathrm{Cu}$ on periphyton. Taking into account these arguments, a higher sensitivity would be expected in $\mathrm{B} 2$, which had the lowest water $\mathrm{pH}$ during the channel experiments. This expectation contrasts with the results found: $\mathrm{B} 1$ and $\mathrm{T} 1$ showed marked differences in $\mathrm{EC}_{50}$ 's in spite of having similar water $\mathrm{pH}$. We can therefore conclude that $\mathrm{pH}$ has not played a decisive role in explaining differences in the $\mathrm{Cu}$ sensitivity of natural periphyton in our experiments.

Differences in copper sensitivity between different periphyton communities have also been attributed to the protective role of biomass (Admiraal et al. 1999; Navarro et al. 2002; Guasch et al. 2003). Barranguet et al. (2002) suggested that the dependence between periphyton biomass and $\mathrm{Cu}$ toxicity was related to its unspecific mode of action. $\mathrm{Cu}$ toxicity was progressive by indiscriminately damaging the algae at or protruding progressively from the biofilm surface to deeper biofilm layers, thus, the magnitude of the effect depended on the initial biomass in the short term (Guasch et al. 2004). In our investigation, although the periphyton communities presented differences in algal biomass, a long duration of the toxicity tests $(18 \mathrm{~h})$ was specifically selected to allow the metal to attain the deeper layers of the biofilm, minimizing the possible influence of algal biomass on the toxicological response of periphyton. Differences in the $\mathrm{Cu}$ sensitivity 
of natural communities could also be attributed to different algal taxa. However, taking into account that metal sensitivity is species-specific (Hutchinson and Stokes 1975), the taxonomic resolution obtained in our study (done at algal group level) did not allow us to derive this information.

Several ecological implications may be suggested if the experimental results obtained are extrapolated to the ecosystem scale. Based on the results of this study, it is suggested that periphyton communities in fluvial systems draining forested areas will be more sensitive to copper since these sites will have low phosphate concentrations. In addition, oligotrophic sites will also have a low probability of receiving metal inputs due to the dominating land use. On the other hand, periphyton communities located in more human-impacted areas will suffer from both eutrophication and potential metal inputs, as has been reported in previous studies (Guasch et al. 2009), and are expected to be more tolerant to $\mathrm{Cu}$.

Acknowledgments This study was supported by two Spanish Ministry projects (REN2003-07702 and CGL2006-12785) and the EC project KEYBIOEFFECTS (MRTN-CT-2006-035695).

Open Access This article is distributed under the terms of the Creative Commons Attribution Noncommercial License which permits any noncommercial use, distribution, and reproduction in any medium, provided the original author(s) and source are credited.

\section{References}

Admiraal W, Blanck H, Buckert-De Jong M, Guasch H, Ivorra N, Lehmann V, Nyström BAH, Paulsson M, Sabater S (1999) Short-term toxicity of zinc to microbenthic algae and bacteria in a metal-polluted stream. Water Res 33:1989-1996

American Public Health Association (APHA) (1989) Standard methods for the examination of water and wastewater, 17th ed. Washington, DC

Andrade LR, Farina M, Filho AMG (2004) Effects of copper on Enteromorpha flexuosa (Chlorophyta) in vitro. Ecotox Environ Safe 58:117-125

Barranguet C, Plans M, Van der Grinten E, Sinke JJ, Admiraal W (2002) Development of photosynthetic biofilms affected by dissolved and sorbed copper in a eutrophic river. Environ Toxicol Chem 9:1955-1966

Boston HL, Hill WR, Stewart AJ (1991) Evaluating direct toxicity and food-chain effects in aquatic systems using natural periphyton communities. In: Gorsuch JW, Lower WR, Wang W (eds) Plants for toxicity assessment, vol 2. American Society for Testing and Materials, Philadelphia, pp 126-145

Cairns J Jr, Niederlehner BR (1987) Problems associated with selecting the most sensitive species for toxicity testing. Hydrobiologia 153:87-94

Campbell PGC (1995) In: Metal speciation and bioavailability in aquatic systems; Tessier A, Turner DR (eds) John Wiley and Sons, Chichester. Vol 3, pp 45-102

Carpenter SR, Caraco NF, Correll DL, Howarth RW, Sharpley AN, Smith VH (1998) Nonpoint pollution of surface waters with phosphorus and nitrogen. Ecol Appl 8:559-568
Chen C-Y (1994) Theoretical evaluation of the inhibitory effects of mercury on algal growth at various orthophosphate levels. Water Res 28:931-937

Clements WH, Newman MC (2002) Community ecotoxicology. John Wiley and Sons (ed), Chichester, UK

Drábková M, Matthijs HCP, Admiraal W, Maršálek B (2007) Selective effects of $\mathrm{H} 2 \mathrm{O} 2$ on cyanobacterial photosynthesis. Photosynthetica 46:363-369

Eckholm P, Kallio K, Salo S, Pietilänien O-P, Rekolanien S, Laine Y, Joukola M (2000) Relationship between catchment characteristics and nutrient concentrations in an agricultural river system. Water Res 34:3709-3716

Genter RB (1996) Ecotoxicology of inorganic chemical stress to algae. In: Stevenson RJ, Bothwell ML, Lowe RL (eds) Algal ecology. Freshwater benthic ecosystems. Academic Press, San Diego, pp 403-468

Guasch H, Sabater S (1995) Seasonal variation in photosynthesisirradiance responses by biofilms in Mediterranean streams. J Phycol 31:725-735

Guasch H, Paulsson M, Sabater S (2002) Effect of copper on algal communities from oligotrophic calcareous streams. J Phycol $38: 241-248$

Guasch H, Admiraal W, Sabater S (2003) Contrasting effects of organic and inorganic toxicants on freshwater periphyton. Aquat Toxicol 64:165-175

Guasch H, Navarro E, Serra A, Sabater S (2004) Phosphate limitation influences the sensitivity to copper in periphytic algae. Freshw Biol 49:463-473

Guasch H, Leira M, Montuelle B, Geiszinger A, Roulier JL, Tornés E, Serra A (2009) Use of multivariate analyses to investigate the contribution of metal pollution to diatom species composition: search for the most appropriate cases and explanatory variable. Hydrobiologia 627:143-158

Guillard RR, Lorenzen CJ (1972) Yellowgreen algae with chlorophyllide c. J Phycol 8:10-14

Hall J, Healey FP, Robinson GGC (1989) The interaction of chronic copper toxicity with nutrient limitation in two chlorophytes in batch culture. Aquat Toxicol 14:1-14

Harding JPC, Whitton BA (1977) Environmental factors reducing the toxicity of zinc to Stigeoclonium tenue. Br Phycol J 12:17-21

Hashemi F, Leppard GG, Kushner DJ (1994) Copper resistance in Anabaena variabilis - effects of phosphate nutrition and polyphosphate bodies. Microb Ecol 27:159-176

Horne AJ, Goldman CR (1994) Limnology, 2nd edn. McGraw Hill, New York

Hutchinson TC, Stokes PM (1975) Heavy metal toxicity and algal bioassays. ASTM special technical publication 573:320-343

Interlandi SJ (2002) Nutrient-toxicant interactions in natural and constructed phytoplankton communities: results of experiments in semicontinuous and batch culture. Aquat Toxicol 61:35-51

Ivorra N, Hettelaar J, Tubbing GMJ, Kraak MHS, Sabater S, Admiraal W (1999) Translocation of microbenthic algal assemblages used for in situ analysis of metal pollution in rivers. Arch Environ Contam Toxicol 37:19-28

Ivorra N, Hettelaar J, Kraak MHS, Sabater S, Admiraal W (2002) Responses of biofilms to combined nutrient and metal exposure. Environ Toxicol Chem 19:626-632

Jeffrey SE, Humphrey GF (1975) New spectrophotometric equations for determining chlorophylls $-\mathrm{a},-\mathrm{b}$ and $-\mathrm{c}$ in higher plants, algae and natural phytoplankton. Biochem Physiol Pflanzen 167: 191-194

Jensen TE, Baxter M, Rachlin JW, Jani V (1982) Uptake of heavy metals by Plectonema boryanum (Cyanophycea) into cellular components, especially polyphosphate bodies: an X-ray energy dispersive study. Environ Pollut Ser A Ecol Biol 27:119-127 
Johnson GD, McIntosh AW, Atchison GJ (1978) The use of periphyton as a monitor of trace elements in two contaminated Indiana Lakes. Bull Environ Contam Toxicol 19:733-740

Johnson LB, Richards C, Host GE, Arthur JW (1997) Landscape influences on water chemistry in Midwestern stream ecosystems. Freshw Biol 37:193-208

López-Flores R, Quintana XD, Salvadó V, Hidalgo M, Sala LL, Moreno-Amich R (2003) Comparison of nutrient and contaminant fluxes in two areas with different hydrological regimes (Empordà Wetlands, NE Spain). Water Res 37:3034-3046

Luoma SN (1983) Bioavailability of trace metals to aquatic organisms-a review. Sci Total Environ 28:1-22

Ma M, Zhu W, Wang Z, Witkamp G (2003) Accumulation, assimilation and growth inhibition of copper on freshwater alga (Scenedesmus subspicatus 86.81 SAG) in the presence of EDTA and fulvic acid. Aquat Toxicol 63:221-228

Meador JP (1991) The interaction of $\mathrm{pH}$, dissolved organic carbon, and total copper in the determination of ionic copper and toxicity. Aquat Toxicol 19:13-32

Meylan S, Odzak N, Behra R, Sigg L (2004) Speciation of copper and zinc in natural freshwater: comparison of voltammetric measurements, diffusive gradients in thin films (DGT) and chemical equilibrium models. Anal Chim Acta 510:91-100

Nalewajko C, Olaveson MM (1994) Differential responses of growth, photosynthesis, respiration, and phosphate uptake to copper in copper-tolerant and copper-intolerant strains of Scenedesmus acutus (Chlorophyceae). Can J Bot 73:1295-1303

Nalewajko C, Paul B (1985) Effects of manipulations of aluminium concentrations and $\mathrm{pH}$ on phosphorus uptake and photosynthesis of planktonic communities in two Precambrian Shield lakes. Can J Fish Aquat Sci 42:1946-1953

Navarro E, Guasch H, Sabater S (2002) Use of microbenthic algal communities in ecotoxicological tests for the assessment of water quality: the Ter river case study. J Appl Phycol 14:41-48

Nriagu JO (1979) The global copper cycle. In: Nriagu JO (ed) Copper in the environment. Part I. Ecological cycling. John Wiley, New York, pp 1-17

OECD (Organization for Economic Cooperation, Development) (1982) Eutrophication of waters: monitoring. Assessment and control. Organisation for Economic and Cooperative Development Paris, France

Paulsson M, Månsson V, Blanck H (2002) Effects of zinc on the phosphorus availability to periphyton communities from the river Göta Älv. Aquat Toxicol 56:103-113

Peterson HG, Healey FP, Wagemann R (1984) Metal toxicity in algae: a highly $\mathrm{pH}$ dependent phenomenon. Can J Fish Aquat Sci 41:974-979

Ramelow GJ, Biven SL, Zhang Y, Beck JN, Young JC, Callahan JD, Marcon MF (1992) The identification of point sources of heavy metals in an industrially impacted waterway by periphyton and surface sediment monitoring. Water Air Soil Poll 65:175-190

Rhee G-Y (1972) Competition between an alga and an aquatic bacterium for phosphate. Limnol Oceanogr 7:505-514
Rhee G-Y (1973) A continuous culture study of phosphate uptake, growth rate and polyphosphate in Scenedesmus sp. J Phycol 9:495-506

Riedel GF, Sanders JG (2003) The interrelationships among trace element cycling, nutrient loading, and system complexity in estuaries: a mesocosm study. Estuaries 26:339-351

Rijstenbil JW, Dehairs F, Ehrlich R, Wijnholds JA (1998) Effect of the nitrogen status on copper accumulation and pools of metalbinding peptides in the planktonic diatom Thalassiosira pseudonana. Aquat Toxicol 42:187-209

Romaní AM, Sabater S (1999) Epilithic ectoenzyme activity in a nutrient-rich Mediterranean river. Aquat Sci 61:122-132

Rysgaard S, Kuhl M, Glud RN, Hansen JW (2001) Biomass, production and horizontal patchiness of sea ice algae in a high-Arctic fjord (Young Sound, NE Greenland). Mar Ecol Prog Ser 223:15-26

Sabater S, Guasch H, Ricart M, Romaní A, Vidal G, Klünder C, Schmitt-Jansen M (2007) Monitoring the effect of chemicals on biological communities. The biofilm as an interface. Anal Bioanal Chem 387:1425-1434

Say PJ, Whitton BA (1977) Influence of zinc on lotic plants. Environmental effects on toxicity of zinc to Hormidium rivulare. Freshw Biol 7:377-384

Schulze H, Brand JJ (1978) Lead toxicity and phosphate deficiency in Chlamydomonas. Plant Physiol 62:727-730

Serôdio J, Marques da Silva J, Catarino F (1997) Nondestructive tracing of migratory rhythms of intertidal benthic microalgae using in vivo chlorophyll a fluorescence. J Phycol 33:542-553

Stadorub ME, Wong PTS, Mayfield CI, Chau YK (1987) Influence of complexation and $\mathrm{pH}$ on individual and combined heavy metal toxicity to a freshwater green alga. Can J Fish Aquat Sci 44: $1173-1180$

Stumm W, Morgan JJ (1981) Aquatic chemistry, 2nd edn. Wiley, New York

Sunda WG, Huntsman SA (1998) Processes regulating cellular metal accumulation and physiological effects: phytoplankton as model systems. Sci Total Environ 219:165-181

Twiss MR, Nalewajko C (1992) Influence of phosphorus nutrition on copper toxicity to three strains of Scenedesmus acutus (Chlorophyceae). J Phycol 28:291-298

Van der Grinten E, Janssen M, Simis SGH, Barranguet C, Admiraal W (2004) Phosphate regime structures species composition in cultured phototrophic biofilms. Freshw Biol 49:369-381

Van Kooten O, Snel JFH (1990) The use of chlorophyll fluorescence nomenclature in plant stress physiology. Photosynth Res 25:147-150

Verma SK, Singh RK, Singh SP (1993) Copper toxicity and phosphate utilization in the cyanobacterium Nostoc calcicola. Bull Environ Contam Toxicol 50:198

Wang WS, Dei RCH (2001) Effects of major nutrient additions on metal uptake in phytoplankton. Environ Pollut 111:233-240

Wang W-X, Dei RCH (2006) Metal stoichiometry in predicting Cd and $\mathrm{Cu}$ toxicity to a freshwater green alga Chlamydomonas reinhardtii. Environ Pollut 142:303-312 